This item was submitted to Loughborough's Research Repository by the author.

Items in Figshare are protected by copyright, with all rights reserved, unless otherwise indicated.

\title{
Effect of systemic transplantation of bone marrow-derived mesenchymal stem cells on neuropathology markers in APP/PS1 Alzheimer mice
}

\section{PLEASE CITE THE PUBLISHED VERSION}

http://dx.doi.org/10.1111/nan.12319

\section{PUBLISHER}

(C) John Wiley and Sons

\section{VERSION}

AM (Accepted Manuscript)

\section{PUBLISHER STATEMENT}

This work is made available according to the conditions of the Creative Commons Attribution-NonCommercialNoDerivatives 4.0 International (CC BY-NC-ND 4.0) licence. Full details of this licence are available at: https://creativecommons.org/licenses/by-nc-nd/4.0/

\section{LICENCE}

CC BY-NC-ND 4.0

\section{REPOSITORY RECORD}

Naaldijk, Yahaira, Carsten Jaeger, Claire Fabian, Christiane Leovsky, A. Blüher, Lukas Rudolph, Arnd Hinze, and Alexandra Stolzing. 2016. "Effect of Systemic Transplantation of Bone Marrow-derived Mesenchymal Stem Cells on Neuropathology Markers in APP/PS1 Alzheimer Mice". Loughborough University. https://hdl.handle.net/2134/20646. 
Received Date : 06-Jul-2015

Revised Date :29-Jan-2016

Accepted Date : 17-Feb-2016

Article type : Original Article

\title{
Effect of systemic transplantation of bone marrow-derived mesenchymal stem cells on neuropathology markers in APP/PS1 Alzheimer mice
}

\author{
${ }^{1,2^{*}}$ Y. Naaldijk, ${ }^{3 *} \mathrm{C}$. Jäger, ${ }^{1,2} \mathrm{C}$. Fabian, ${ }^{1} \mathrm{C}$. Leovsky, ${ }^{1} \mathrm{~A}$. Blüher, ${ }^{1} \mathrm{~L}$. Rudolph, ${ }^{1} \mathrm{~A}$. Hinze,${ }^{1,2,4} \mathrm{~A}$ \\ Stolzing
}

${ }^{1}$ Fraunhofer Institute for Cell Therapy and Immunology (IZI), Leipzig, Germany

${ }^{2}$ Translational Centre for Regenerative Medicine (TRM), University of Leipzig, Leipzig,

Germany

${ }^{3}$ Paul Flechsig Institute for Brain Research, University of Leipzig, Leipzig, Germany

${ }^{4}$ Loughborough University, Loughborough, England

*Shared first author

Running title: Alzheimer stem cell therapy

Institute at which the work was performed: Fraunhofer Institute for Cell Therapy and Immunology (IZI), Leipzig, Germany

\section{Corresponding author:}

Alexandra Stolzing, Wolfson School of Mechanical and Manufacturing Engineering Loughborough University, Epinal Way, LE113TU Loughborough, UK

This article has been accepted for publication and undergone full peer review but has not been through the copyediting, typesetting, pagination and proofreading process, which may lead to differences between this version and the Version of Record. Please cite this article as doi: 10.1111/nan.12319

This article is protected by copyright. All rights reserved. 
Tel.: 0044-1509-227577

A.Stolzing@lboro.ac.uk

Key words: Amyloid, mesenchymal stem cells, microglia, Alzheimer's disease, astrocytes

\section{Abstract}

\section{Aims}

Mesenchymal stem cells (MSC) have recently attracted interest as a potential basis for a cell based therapy of $A D$. We investigated the putative immune-modulatory effects in neuroinflammation of systemic transplantation of MSC into APP/PS1 transgenic mice.

\section{Methods}

$10^{6} \mathrm{MSC}$ were injected into APP/PS1 mice via the tail vein and histological analysis was performed for microglia and amyloid ( $p E 3-A \beta$ ) plaque numbers, glial distribution and $p E 3-A \beta$ plaque size. In addition, a biochemical analysis by qPCR for pro-inflammatory, chemoattractant and neurotrophic factors was performed.

\section{Results}

MSC co-localized with $\mathrm{pE} 3-\mathrm{A} \beta$ plaques. The effects of transplantation on microgliaassociated pathology could be observed after 28 hours. Animals showed a reduction in microglial numbers in the cortex and in size. Gene expression was reduced for TNF- $\alpha$, IL-6, MCP-1, and for NGF, in MSC recipients. Also, we investigated for the first time and found no changes in expression of IL-10, CCR5, BDNF, VEGF and IFNY. PTGER2 expression levels were increased in the hippocampus but were reduced in the cortex of MSC recipients. While there were no transplant-related changes in $\mathrm{pE} 3-\mathrm{A} \beta$ plaque numbers, a reduction in the size of $p E 3-A \beta$ plaques was observed in the hippocampus of transplant recipients.

\section{Conclusion}

This is the first study to show reduction in $p E 3-A \beta$ plaque size. $p E 3-A \beta$ plaques have gained attention as potential key participants in $A D$ due to their increased aggregation propensity, the possibility for the initial seeding event, resistance against degradation and neurotoxicity. These findings support the hypothesis that MSC-transplants may affect AD pathology via an immune modulatory function that includes an effect on microglial cells.

This article is protected by copyright. All rights reserved. 


\section{Introduction}

Alzheimer's disease (AD) is a neurodegenerative disease marked histopathologically by amyloid $\beta$ aggregations, neurofibrillary tangles, and neuronal impairment finally leading to memory impairments (1). Some reports suggest the role of oxidative and inflammatory stress together with microglia changes preceding the onset of clinical and pathological $A D$ symptoms (2-5).

Mesenchymal stem cells (MSC) have recently attracted interest as a potential basis for a cell based Alzheimer therapy (6-8) but apart from their clinical potential their mechanism of action has yet to be ascertained.

One potential approach is to study the impact of MSC on microglia, the resident macrophages of the brain. Microglia show early signs of dysfunction in AD (9). The microglia can either be neuroprotective or neurotoxic depending on the secretion profile and surface marker expression $(10,11)$. Activated microglia secrete a variety of pro-inflammatory cytokines including interleukin-6 (IL-6) and tumour necrosis factor-a (TNF-a), which induce neuroinflammation (12). Microglia also participate in the recruitment of cells into the brain and to $A D$ associated amyloid plaques through chemokine secretion, such as monocyte chemotactic protein-1 (MCP-1) (13-15). However, microglia are also known to produce neurotrophic factors such as brain-derived neurotrophic factor (BDNF), neuronal growth factor (NGF) and vascular endothelial growth factor (VEGF/A), providing trophic support to neurons.

Previous studies in AD mice have been performed using intracranial application of MSC. These studies showed promising results however they had several drawbacks including the use of human cells in an animal model and an invasive intra-cerebral transplantation delivery method $(16,17)$. There have at present been no studies using systemic MSC injections. One study used systemic injections, however the cells used were described as bone marrow derived cells and not described or characterised as MSC. Additionally, in the same study the animals were also irradiated (18).

In summary this demonstrated the need for a study that systemically applied MSC via injections to an $A D$ mouse model. Also for translational purposes we were interested in testing a minimally invasive method of cell administration using systemic injection.

We found that MSCs were able to migrate into the brain and reduced the amount of middle sized $p E 3-A \beta$ amyloid plaques. Microglial numbers were not changed, however, we found that microglia and astrocyte activation levels were decreased. In addition, the expression of several important inflammatory markers were reduced in AD mice transplanted with MSC in comparison to control animals.

This article is protected by copyright. All rights reserved. 


\section{Material and methods}

\section{Animals}

Transgenic mice overexpressing human amyloid precursor protein (APP ${ }^{\mathrm{KM} 670 / 671 \mathrm{NL}}$ ) and presenilin-1 (PS1 ${ }^{\mathrm{L} 166 \mathrm{P}}$ ) under Thy-1 promoter control (age 12-15 months) were obtained from University of Leipzig (Prof. Bechmann) and the German Centre for Neurodegenerative Diseases (Prof. M. Jucker,) Tübingen (19). C57BL/6 from the MEZ of the University of Leipzig or Charles River were used as a source for bone marrow derived MSC. GFPtransgenic mice (12 weeks) were from the Paul Flechsig Brain Research Institute, University of Leipzig. The experiments were approved by the local Animal Welfare Committee of the University of Leipzig and by the local governmental authorities (Landesdirektion Sachsen, permit numbers T70/12, T72/13, TVV 07/08).

\section{MSC preparation}

Bone marrow was cultured in DMEM low glucose (Gibco, 21885-108) with 10\% fetal calf serum (Hyclone, SV30160.03) and 1\% penicillin / streptomycin (Gibco, 15070-063). Briefly, mouse bone marrow cells were obtained centrifugally from tibiae and femurae and cultured according to the methods of Dobson et al. (20). MSC were isolated by the methods of Sekiya et al. (21). MSC were passaged when they were 70\% confluent using trypsin (Trypsin-EDTA $0.25 \%$ Gibco). Identity was confirmed by staining for MSC specific markers (CD11', CD45; $\left.\mathrm{CD}_{4}{ }^{+}, \mathrm{CD}^{+} 0^{+}, \mathrm{CD} 105^{+}, \mathrm{CD}_{133^{+}}, \mathrm{CD} 146^{+}, \mathrm{sca}-1^{+}\right)$and mesodermal lineage differentiation (data see supplement). MSC were used for transplantations at passage 1-2.

\section{Mesodermal lineage differentiation}

Murine BM-MSC were analysed for their differentiation potential at passage 3.

Osteogenic differentiation: Cells were seeded at $1 \times 10^{4}$ cells $/ 1.9 \mathrm{~cm}^{2}$ (24 well-plate, GreinerBioOne, 662160) and cultured with osteogenic medium (DMEM low glucose (Gibco, 21885-108); 10\% FBS (Hyclone, SV30160.03); 1\% Pencillium/Strepromycin (Gibco, 15070063); $10 \mathrm{nM}$ dexamethasone (Sigma-Aldrich, D4902); $50 \mu \mathrm{g} / \mathrm{ml}$ ascorbic acid 2-phosphate (Sigma-Aldrich, A8960-5G). Medium was changed every 2 days. After 14 days qualitative analysis was done: Cells were fixed with 70\% Ethanol (VWR445363) and stained for alkaline phosphatase with Fast Red (0.2 M Tris (Sigma-Aldrich 459836); 1 mg/ml Fast Red (SigmaAldrich 51503); $50 \mu \mathrm{g} / \mathrm{ml}$ naphtol phosphate AS-BI (Sigma-Aldrich) for 1 hour.

Adipogenic differentiation: Cells were seeded at $2 \times 10^{4}$ cells / $1.9 \mathrm{~cm}^{2}$ (24 well-plate, GreinerBioOne, 662160) and cultured with for 7 days with a 1:1 mixture of culture medium (DMEM high glucose (Gibco, 31966-047); 1\% Pencillium/Streptomycin (Gibco, 15070-063); 10\% FBS (Hyclone, SV30160.03)) and adipogenic medium (culture medium with additionally $10 \%$ insulin-transferrin-selenium supplement, (Sigma-Aldrich, I3146-5ML) $10 \mathrm{nM}$ dexamethasone (Sigma-Aldrich, D4902); $0.5 \mathrm{mM}$ isobutylmethylxanthine (Sigma-Aldrich, 
17018); $100 \mu \mathrm{M}$ indomethacin (Sigma-Aldrich, 17378-10G)). After 7 days cells were culture only in adipogenic medium. Medium was changed every 2-3 days. After 14 days qualitative analysis was done: Cells were fixed with $4 \%$ buffered PFA (Thermo Fisher, 28908) and stained with $0.45 \%$ Oil Red O (Sigma-Aldrich, O0625) in isopropanol (Applichem).

Chondrogenic differentiation: Cells were seeded at $5 \times 10^{4}$ cells / $3.9 \mathrm{~cm}^{2}$ (12 well-plate, GreinerBioOne, 662180) and cultured with osteogenic medium (DMEM high glucose (Gibco, 31966-047); 10\% FBS (Hyclone, SV30160.03); 1\% Pencillium/Strepromycin (Gibco, 15070063); $100 \mathrm{nM}$ dexamethasone (Sigma-Aldrich, D4902), $150 \mu \mathrm{M}$ ascorbic-2-phosphate (Sigma-Aldrich, A8960-5G), $20 \mu \mathrm{M}$ linoic acid (Sigma-Aldrich, L1012) and $10 \mathrm{ng} / \mathrm{ml}$ TGF- $\beta$ (Invitrogen, PHG9214). Medium was changed every 2-3 days. After 14 days qualitative analysis was done: Cells were fixed with $4 \%$ buffered PFA (Thermo Fisher, 28908) and stained with Alcian blue under acidic conditions ( $\mathrm{pH} 2.5$ ).

\section{MSC phenotyping}

Murine BM-MSC were analysed for their CD phenotype at passage 1. Cells were harvested by trypsinization and stained with the following antibodies: IgG-FITC (Serotec STAR70, 1:200), CD11b-FITC (Abcam ab99671, 1:50), CD44-Alexa 488 (Biolegend 103015, 1:50), CD45-FITC (Biotec 1660-02S, 1:50), CD90-FITC (1:100; 4 ; 30min; Serotec), CD105Alexa 488 (Biozol 120405, 1:50), CD133-FITC (Abcam ab97022, 1:200), CD146 (BD Bioscience 553336, 1:50) and sca-1 (BD Bioscience 562196, 1:50) Dil and DiO (Molecular Probes/Fischer, $3 \mu \mathrm{l} / \mathrm{ml})$ ). MSC were then analysed using the personal flow cytometry system (Beckman Coulter).

\section{Transplantation}

For histological analysis $10^{6} \mathrm{MSC}$ in $150 \mu \mathrm{l} \mathrm{NaCl}$ from female/male donors were injected per male animal (day $7 n=3$ and day $28 n=4$ ) via the tail vein and for biochemistry analysis $10^{6}$ MSC in $150 \mu \mathrm{l} \mathrm{NaCl}$ from male donors were injected into female recipients (day 28, $n=3$ ). The control mice were injected with $150 \mu \mathrm{NaCl}(n=11)$. After 7 or 28 days animals were sacrificed and the organs isolated for biochemical or histological analysis. In some cases we used MSC from eGFP transgenic mice.

\section{Tissue preparation}

Mice were perfused 7 and 28 days after transplantation. For biochemistry, mice were perfused transcardially after death with $0.9 \% \mathrm{NaCl}$. Brains were removed, divided into 5 regions (hippocampus, cortex, cerebellum, brain stem and olfactory bulb) and stored in peqGOLD TriFast ${ }^{\mathrm{TM}}$ (PeqLab, 30-2040) at $80^{\circ} \mathrm{C}$ until further use as well as the pieces of 9 peripheral organs.

For histology, mice were perfused transcardially after death with $0.9 \% \mathrm{NaCl}$ followed by fixative containing $4 \%$ paraformaldehyde and $0.1 \%$ glutaraldehyde in $0.1 \mathrm{M}$ phosphate buffer $(\mathrm{pH} 7.4)$. Brains were removed and immersion-fixed overnight in the same fixative at $4^{\circ} \mathrm{C}$. Brains were cryoprotected in $30 \%$ sucrose in $0.1 \mathrm{M}$ phosphate buffer $(\mathrm{pH} 7.4)$ with $0.1 \%$

This article is protected by copyright. All rights reserved. 
sodium acid, cut into $40 \mu \mathrm{m}$ slices with a cryomicrotome in frontal plane, slices were collected in $0.1 \mathrm{M}$ phosphate buffer $(\mathrm{pH} 7.4)$ with $0.1 \%$ sodium acid.

\section{Immunohistochemistry}

Histochemistry was performed with free-floating sections. Brain slices were washed once with PBS containing $0.05 \%$ Tween $^{20}$ (Sigma-Aldrich, P2287-100ML) (PBS-T). All washing steps were performed 3 times for 5 minutes in PBS-T. Quenching of endogenous peroxidase enzyme activity was performed by using $2 \% \mathrm{H}_{2} \mathrm{O}_{2}$ (VWR Prolabo, 23622.298) in 60\% methanol (VWR Prolabo, BDH1135) for 60min for staining with 3,3'-Diaminobenzidine (DAB, Roth, CN75.1). Sections were incubated in blocking solution consisting of PBS-T plus $2 \%$ bovine serum albumin (Serva, 11930), 0.3\% milk powder (Roth, T145), and 0.5\% donkey normal serum (Jackson Immuno Research, 017-000-001) for 30 min prior to incubation with the primary antibody.

All slices used were incubated overnight at $4^{\circ} \mathrm{C}$ in blocking solution and primary antibody. The primary antibodies used were: anti-lba-1 (rabbit, 1:600; Wako), anti-pyroglutamate-beta amyloid (pE3-A $\beta$ ) (mouse, 1:500; Synaptic Systems) and anti-GFAP antibody (rabbit, 1:700; DAKO). After washing 3 times in PBS-T, the biotinylated secondary donkey-anti-mouse IgG antibody (1:1000; Dianova) or donkey-anti-rabbit lgG antibody (1:1000; Dianova) was applied for $1 \mathrm{~h}$ in solution containing $50 \%$ blocking solution and $50 \%$ PBS-T. Sections were washed 3 times in PBS-T and incubated in peroxidase-coupled extravidin (1:2000, SigmaAldrich, E2886) for $1 \mathrm{~h}$ in 1 part blocking solution and 2 parts PBS-T, followed by washing and incubation with $0.05 \mathrm{M}$ Tris-buffer $\mathrm{pH} 8$ for $5 \mathrm{~min}$. Subsequently, brains were placed in $10 \mathrm{ml} 0.05 \mathrm{M}$ Tris-buffer ( $\mathrm{pH} 8$ ), 4mg DAB and $5 \mu \mathrm{l} 30 \% \mathrm{H}_{2} \mathrm{O}_{2}$ until a colour change was visible. For $\mathrm{pE} 3-\mathrm{A} \beta$ staining diaminobenzidine with nickel ammonium sulfate (Sigma-Aldrich, 7785-20-8) enhancement (DABNi) was used. A solution of $10 \mathrm{ml}$ Tris-buffer with $40 \mathrm{mg}$ of nickel ammonium sulphate was prepared followed by the addition of $4 \mathrm{mg}$ DAB. After that $5 \mu \mathrm{l}$ $30 \% \mathrm{H}_{2} \mathrm{O}_{2}$ was added to the mixture. Brain slices were incubated in DABNi for 30min. Sections were finally washed, placed on glass slides, dried and mounted with entellan in toluol (Merck, 108323).

Immunofluorescence for microglia was carried out with rabbit anti Iba-1 (WAKO, 1:500, 01919741) overnight, followed by secondary antibody donkey-anti-rabbit Cy3 (Dianova, 1:250, 711-165-152) for one hour. Slices for LSM double fluorescence images (Fig. 1) were stained without immunohistochemical enhancement for immigrated eGFP ${ }^{+}$MSC.

Immunohistochemistry for astrocytes was performed as followed: brain slices were mounted on the cover slides. Autofluorescence quenching was performed by incubating the brain slices with Image-IT (Life Technology, 136933) for 30 minutes. After that, brain slides were washed twice with PBS followed by incubation with blocking solution for 30 minutes. Then, rabbit anti-GFAP antibody (1:700; DAKO, Z033429-2) in blocking solution was added to the brain slices and incubated over night at $4^{\circ} \mathrm{C}$. Next, brain slices were washed 3 times with

This article is protected by copyright. All rights reserved. 
PBS and incubated with donkey anti-rabbit Northern Lite 557 (1:200; R\&D, NL004) for $1 \mathrm{hr}$ followed by washing 3 times with PBS. The nucleus was stained with $0.5 \mu \mathrm{M}$ Sytox Green (Life Technology, S7020) for 30 minutes. Brain slices were mounted using ProLong® Gold Antifade mounting medium (Molecular Probes, P36934). Immunofluorescence for microglia was carried out with rabbit anti lba-1 (WAKO, 1:300-500, 019-19741) overnight, followed by secondary antibody donkey-anti-rabbit Cy3 (Dianova, 1:250, 711-165-152) for one hour. Immunofluorescence for GFP was carried out with goat anti GFP overnight, followed by secondary antibody donkey-anti-goat Cy2 (Dianova, 1:250, 705-225-147) for one hour.

\section{Thioflavin S staining}

Floating brain slices were incubated in $0.5 \%$ Thioflavin S solution (Sigma, T1892-25G) for $5 \mathrm{~min}$ at room temperature. Sections were then washed with $70 \%$ ethanol followed by $50 \%$ ethanol. Each washing step was performed at room temperature for $5 \mathrm{~min}$. After the ethanol washes, the sections were washed once with water for $5 \mathrm{~min}$ at room temperature. Sections were placed on glass slides, dried and mounted with entellan (VWR, 1079600500).

\section{Microscopy and image processing}

Tissue sections were examined with the Keyence BZ-9000 microscope equipped with a BZ9000 Analyser software (Keyence Corporation, USA) for light and fluorescence microscopy. Haze reduction and white/black balance were used to process the images with minimal alterations to the brightness, sharpness, colour saturation and contrast. Fluorescence labelling (Fig.1) was examined with a Zeiss confocal laser scanning microscope (LSM 510, Zeiss, Jena, Germany). For secondary Cy2-labelling (green fluorescence), an argon laser with 488-nm excitation was used and emission from Cy2 was recorded at 510-nm applying a low-range band pass (505-550 nm). For secondary Cy3-labelling (red fluorescence), a helium-neon laser with 543-nm excitation was used and emission from Cy3 at $570 \mathrm{~nm}$ was detected applying a high-range band pass (560-615 nm). Photoshop CS2 (Adobe Systems, Mountain View, CA, USA) was used to process the images with minimal alterations to the brightness, sharpness, colour saturation and contrast.

\section{Stereology}

Microglia (lba-1) and plaque ( $\mathrm{pE} 3-\mathrm{A} \beta$ ) numbers were evaluated for the whole cortex and hippocampus using Zeiss Axio Imager microscope (Carl Zeiss) and quantified by Stereo Investigator 8 software (MBF Bioscience). The distance between each counting frame was $350 \mu \mathrm{m} \times 350 \mu \mathrm{m}$ and a counting frame of $250 \mu \mathrm{m} \times 250 \mu \mathrm{m}$ was used for counting microglia and plaque numbers with $20 x$ objective. Where the results were unclear a higher magnification (40x or $63 \mathrm{x}$ ) was used to distinguish cells residing below another.

Nine sections per animal, taken from beginning to the end of the cortex and hippocampus were examined, at a serial interval of every 10 slices, with a counting frame for the cortex

This article is protected by copyright. All rights reserved. 
200 and hippocampus 70 per slice. The whole left cortex and hippocampus were counted and the numbers multiplied by 2 to cover both hemispheres.

\section{Measurement of pyroglutamate-beta amyloid ( $p E 3-A \beta)$ plaque size}

To determine the amyloid plaque size, pictures from the cortex (4-5 pictures) and hippocampus (3-4 pictures) were randomly taken from one slide of each animal. Analysis was performed in the anterior, middle and posterior hippocampus and cortex. Photos were taken at 20x objective with BZ-9000 Keyence microscope and analysis performed with BZ-II Analyser Software (Keyence). Plaque diameter was determined by measuring the distance between two opposite points at the plaque edge. A line was drawn from the beginning to the end of the plaque and diameter in $\mu \mathrm{m}$ was obtained for each plaque. The software automatically calculated the diameter based on the length of the drawn line.

\section{Microglia covered area measurement}

Microglia covered area was determined using Keyence BZ900 microscope and BZ-II Analyser Software (Keyence). Pictures of lba-1 positive cells (microglia) were taken randomly in the cortex (5 pictures) and hippocampus (4 pictures) for every mouse. Analysis was performed using the Hybrid Cell Count software module in BZ-II Analyser Software. Settings for brightness and threshold were adapted and applied for all measurements. Brightness of lba-1 fluorescence was manually set at a maximum threshold where background was barely present. Threshold was established independently for each mouse. Areas located on corners and holes were manually excluded to reduce noise in the analysis. After setting the brightness parameters lba- $1^{+}$covered area was obtained for every picture. Covered area was calculated as the mean of all images determined for every mouse.

\section{Astrocyte covered area measurement}

Analysis of the total area covered by astrocytes labelled with GFAP antibody was performed in the cortex and hippocampus. Single pictures of the whole brain area were taken at $4 x$ magnification and merged using BZII Analyser Software. Then, the regions of interest were cut out and analysed using the Hybrid Cell Count of the BZII Analyser Software. Settings of brightness and threshold were adapted and applied for all measurements. The threshold was set to identify astrocyte clusters. To determine the covered area as a whole, the picture was re-analysed with the threshold reduced to a minimum to include the whole area.

\section{RNA isolation and quantitative RT-PCR}

Total RNA was extracted from hippocampus and cortex using peqGOLDTrifast ${ }^{\mathrm{TM}}$ reagent according to the manufacturer's instructions (PeqLab, 30-2040). It was treated with DNasel (Life Technologies, EN0521) to remove genomic DNA contamination. This procedure was followed by cDNA synthesis using Superscriptlll-reverse transcriptase (Life Technologies, 18080085) and Oligo (dT) $)_{18}$-Primers (Thermo Scientific, SO132) at $50^{\circ} \mathrm{C}$ for $1 \mathrm{~h}$. cDNA was used as PCR template in a 1:10 dilution and each sample run in triplicate. Quantitative PCR

This article is protected by copyright. All rights reserved. 
was performed using Express SYBR GreenER qPCR Supermix Universal (Life technologies, $1178401 \mathrm{~K}$ ), additional 1x SybrGreen (Life technologies, S-7567) and $0.2 \mu \mathrm{M}$ primer each on the DNA engine Opticon2 (Biorad) (primers see supplement table 1) with the following cycle conditions: primary denaturation at $95^{\circ} \mathrm{C}$ for $3 \mathrm{~min}, 35$ cycles with $30 \mathrm{~s}$ at $95^{\circ} \mathrm{C}, 30 \mathrm{~s}$ at $60^{\circ} \mathrm{C}$ and $30 \mathrm{~s}$ at $72^{\circ} \mathrm{C}$ followed by fluorescence measurement. Absolute quantification was performed for every single gene with three technical repeats per sample. Serial dilutions of plasmid controls with known molecule concentrations were used as a positive control and to generate standard curves for the PCR. Expression of target genes were normalized using 36B4 (large ribosomal protein P0, RPLP0) as reference gene.

\section{Statistical analysis}

Data is presented as the mean of the samples and standard deviation as standard error of the mean (SEM). Statistical analysis was performed using the SigmaPlot 11.0 software (Systat Software Inc.) using one-way ANOVA analysis with a $p$-value $<0.05\left(^{*}\right), p<0.01\left(^{* *}\right)$ and $\left.\mathrm{p}<0.001{ }^{* * *}\right)$ considered statistically significant.

\section{Results}

\section{Confirmatory Tests (MSC profile \& delivery to brain)}

Prior to transplantation, MSCs were characterized by flow cytometry for MSC-specific marker expression and differentiation potential. Mouse-derived MSC showed positive expression for typical MSC markers CD44 and CD90 and negative expression for CD11b and CD45 as well as their ability to differentiate into osteoblasts, adipocytes and chondrocytes (data not shown). Up to 28 days after transplantation, GFP ${ }^{+}=$MSC were observed in hippocampus and cortex (Fig. 1 + Suppl.4). In addition to the MSC found in the brain, MSC were observed in bone marrow, lung and liver (manuscript in preparation). GFP ${ }^{+}$ MSC were found mainly around $A B$ plaques and seemed to be integrated into the corona of resident microglia surrounding these plaques. We did not observe transplant-related acute toxicity or adverse events.

This article is protected by copyright. All rights reserved. 


\section{Amyloid content}

We found no transplant-related changes in total amyloid- $\beta$ content as measured by thioflavin-S staining of plaques at different sizes. However, we did observe changes in the pyroglutamate-beta amyloid ( $p E 3-A \beta$ ) sub-component of amyloid $\beta$ plaques at day 28 (Fig.2, $3)$. When $p E 3-A \beta$ plaques are categorized as small $(<50 \mu \mathrm{m})$, medium $(50-100 \mu \mathrm{m})$ and large $(>100 \mu \mathrm{m})$ as described by Kim et al. (7), we found a treatment-related increase in the number of small size plaques, but decrease in medium size plaques in the hippocampus on day 28 (Fig. 2C). No changes were observed in the cortex on day 28 (Fig.2B) and on day 7 (Fig. 3A, left).

\section{Histology}

The following observations were made in histological analysis: Transplanted MSC (derived from GFP-transgenic mice) were found in and around amyloid plaques (Fig. $1+$ Suppl. Fig 5). A lower amount of $p E 3-A \beta$ was found within vessels of the MSC-treated group compared to controls (Fig. 3B). In addition, we observed $p E 3-A \beta$ accumulation in large astrocytes with processes (Fig. 3C). These cells were mainly seen around amyloid plaques and a reduction in the presence of these processes-bearing astrocytes was observed in the MSC-treated group compared to controls. We observed in the histological analysis variability between the different animals transplanted with MSC and controls indicating that even when all mice were close in age they behave independently.

\section{MSC transplantation effect on microglia}

It is known that MSC exert anti-inflammatory effects. We therefore examined whether APP/PS1 mice receiving MSC transplants showed a reduced microglia activation measured by microglia size, represented by Iba-1 covered area. Quantitative analysis showed that the total area occupied by lba-1 positive microglia was significantly decreased in hippocampus and cortex of mice treated with MSC compared to $\mathrm{NaCl}$ at day 28 (Fig.4D). No significant differences were observed by day 7 in the hippocampus but were seen in the cortex (Suppl. Fig.3D). Microglia numbers were significantly reduced in the cortex but not in the hippocampus of the MSC-treated group compared to controls after 28 days (Fig.4B). No significant change was observed after 7 days (Suppl. Fig.3B).

We observed that in mice receiving MSC that microglia were more regularly distributed in comparison to the more clustered distribution in the control group (Fig.4A\&C; Suppl. Fig.3A \& 3D). In addition, morphological changes were observed after transplantation. In MSCtreated mice, microglia were more ramified with more processes per cell (Fig. 4C inserts).

\section{MSC transplantation effect on astrocytes}

In addition to microglia we wanted to examine whether transplanted MSC exert an effect on astrocyte activation. The analysis revealed changes in astrocytes distribution/area after

This article is protected by copyright. All rights reserved. 
treatment with MSC compared to $\mathrm{NaCl}$ controls. We saw a reduction of GFAP covered area after 7 days, which was somewhat reduced by day 28 (Suppl. Fig.4).

\section{MSC effect on gene expression: inflammation, neurogenesis, chemotaxis}

Inflammation: Expression of TNF- $\alpha$ was reduced in the cortex and hippocampus of the transplant group compared to controls. IL-6 was reduced in the hippocampus only and no effect was found for IL-10 and IFN-y (Fig 5\&6). IL-6 expression was reduced in the hippocampus but not in the cortex. Expression level of PTGER2 was reduced in the cortex but elevated in the hippocampus of MSC transplanted animals compared to controls.

Neurogenesis/Trophic factors: Expression of NGF was reduced in the cortex but not in the hippocampus of the transplant group compared to $\mathrm{NaCl}$ controls. No transplant-related changes were observed in either brain region for BDNF expression levels or for the angiogenesis gene VEGF-A (Fig.6).

Chemotaxis: Expression of MCP-1 was reduced in the cortex and hippocampus of the transplant group compared to $\mathrm{NaCl}$ controls. No changes were observed for CCR5 levels.

\section{Discussion}

The role of neuroinflammation in the pathological progression of $A D$ has been widely discussed $(22,23)$ as well as the pro-inflammatory reaction of microglia triggered by $A \beta$. In the current study, we used the transgenic APP/PS1 mouse model where amyloid plaques appear around week six and a full $A \beta$ pathology by 8 months (19). The age of the recipient animals used in this study ranged from 13 to 15 months. In comparison to other AD mouse models the APP/PS1 mouse strain shows a stronger microgliosis, mimicking human microglial activation observed in AD (19).

Injection of MSC into the tail vein appeared safe and effective: the GFP ${ }^{+}$MSC could be observed around $A \beta$ plaques and were seen to settle between the microglial cells. This clearly indicates the potential of MSC to migrate not just towards the brain but to sites of inflammation therein. Secondly, we demonstrated that one single treatment with systemically transplanted MSC leads to obvious changes in Aß pathology.

Recently, a study showed in the APP Tg2576 mouse model that human adipose stem cells labeled with magnetic nanoparticles reached the site after 1 day (24). Another group reported survival of transplanted GFP ${ }^{+}$MSCs into a (PLP)- $\alpha$-SYN mouse model of multiple system atrophy after 4 weeks of transplantation in substantia nigra and brainstem (25). Our experiments document the presence of the transplanted MSC in the brain parenchyma within 4 weeks of delivery. In contrast to the direct access to the brain via stereotactic injection, systemic delivery of MSC via tail vein injection appeared safe and effective. Transplanted $\mathrm{GFP}^{+} \mathrm{MSC}$ were observed around $A \beta$ plaques and seemed to be integrated into the corona of microglia surrounding the $A B$ deposits, which clearly indicates the potential

This article is protected by copyright. All rights reserved. 
of MSC to migrate not just towards the brain but in addition they are attracted to other sites of inflammation therein. This, on the other hand, reveals a putative involvement in neuroinflammatory processes.

There are three other groups studying the use of MSCs in mice as a potential therapy set up for Alzheimer's (17, 26-29) however, most of these studies used either intracranial transplantation of MSCs or used human MSCs. They also showed a reduction of amyloid plaques after day 7 (28). The effect was no longer observed after 28 days indicating a short term effect of transplanted MSCs independent of the transplantation method. However, previous studies have accomplished amyloid plaque reduction through either multiple rounds of MSC transplantation or higher concentration of MSCs $(8,16,17,30-32)$. Systemic MSC transplantation has only been tested in very young $A D$ mice (4 months) when the mice had not fully developed the Alzheimer pathology (31). Another study investigating systemic MSC transplantation did this for 6.5 months every 2 weeks for 2 months following monthly applications starting at age of 7 months $(30,31)$. In none of the publications was a single application of MSCs tested to demonstrate the efficiency.

$A D$ is characterized by the presence of increased levels of pro-inflammatory cytokines (33) mainly produced by aged microglia and astrocytes (34). Here we sought to explore the effect of MSC transplantation on general expression levels of genes related to inflammation, neurogenesis and chemotaxis.

The fact that at each time point analysed some factors showed no transplant-related changes in gene expression, inflammation (IL-10, IFNY), neurogenesis (VEGF-A, BDNF), chemotaxis (CCR5) indicates clearly that the effects of MSCs are not ubiquitous or necessarily on a broad spectrum and require a differentiated analysis.

Yet in other respects, effects were found at each time point observed. Most notably in the neuroinflammation group, we observed a transplant-related reduction of TNF- $\alpha$ gene expression which is known to have a prominent role in AD disease progression maybe even initiating pathological changes $(35,36)$. The increasing expression of TNF- $\alpha$ in the cortex was shown in a triple transgenic $A D$ mouse model at early pre-pathological time points, correlating with enhanced activation of microglia (37). In this mouse model, inflammatory changes also correlate with cognitive deficits and synaptic dysfunction $(38,39)$ and overexpression of TNF- $\alpha$ made a major contribution to neuronal death (40) whereas inhibition of TNF- $\alpha$ in an AD mouse model resulted in lower amyloid beta levels and cognitive impairment (41). In line with our findings, Kim et al. 2013 could also show downregulation of TNF- $\alpha$ up to 12 weeks after intravenous administration of human amniotic (placenta derived) stem cells in an APPswe (Tg2576) Alzheimer mouse model (7), others have demonstrated similar effects after intracranial application of MSCs $(17,42,43)$. Less

This article is protected by copyright. All rights reserved. 
pronounced than for TNF- $\alpha$, expression levels of IL-6, another pro-inflammatory cytokine, was also reduced in the hippocampus but not in the cortex.

In the neurogenesis group, we found MSC transplantation associated with a reduction in NGF expression. Perhaps surprisingly this could be construed as having a potential therapeutic benefit. While NGF supports survival, regulation and differentiation of neurons and neuronal stem cells (44), it is also associated with disturbed neurogenesis in AD (4547). High NGF levels result in impaired neocortical choline acetyl transferase (ChAT) activity which is linked to dementia and might be correlated with the memory loss observed in $A D$ $(48,49)$. A reduction in NGF correlates with changes in microglial morphology and distribution. It is known that reactive microglia encourage pro-NGF expression resulting in detrimental effects (50).

Since we analysed the NGF expression on mRNA level, we did not distinguish between proNGF and mature NGF. Pro-NGF is elevated in AD patients (44) and is normally produced by microglia. The pro-NGF in AD is impaired (51) and subsequently induces apoptosis in neurons. Hence, the reduction on the expression level of NGF in this study could be beneficial in regard to a lower level of proNGF.

The most direct indication of the complexity of MSC immune-modulatory effects is exemplified by our findings for prostaglandin E2 receptor (PTGER2), a pro-inflammatory factor, highly elevated in $A D$ patients and implicated in $A D$ progression $(52,53)$. PTGER2 can be neurotoxic (54), but on the other hand PTGER2 signalling is implicated for its potential role in long-term synaptic plasticity and cognitive function (55). The observed MSCrelated decreased expression of PTGER2 in the cortex while increased in the hippocampus requires further study.

During $A D, M C P-1$ expression is increased, attracting monocytes and microglia which account for pathological gliosis in AD (56). Here we show that transplanted MSCs are able to down-regulate MCP-1 levels - and a corresponding reduction in microglial numbers at least in the hippocampus was observed. Others in this field have observed a transplant-related increase in microglial levels (57) or no change over time (7).

While the number of microglia may not be a good indicator of potential therapeutic action, changes in activation status might be more significant. Microglia exist in many different activation states (58). Aggregated $A \beta$ is known to induce microglial activation (59). In this context, we find a transplant-associated reduction in large-sized microglia which are deemed indicative of an activated state (60). Such an effect was also found by Kim et al. (31) following systemic injection of placenta derived hMSC into APPswe (Tg2576) AD mice. The group observed an initial increase in microglial size, later followed by a size reduction, indicating that any studies into the immune-modulatory and anti-inflammatory dynamics of transplanted MSC are very time point dependent. This is also demonstrated by our observations shown in the supplementary data. Ultimately, to use the immune modulatory

This article is protected by copyright. All rights reserved. 
properties of MSCs for therapeutic purposes, the long-term effects on AD disease progression will need to be investigated as well as the benefits of follow-up transplantation of MSC.

In summary, these findings support the hypothesis that MSC-transplants may affect $A D$ pathology via an immune modulatory function that includes an effect on microglia cells.

\section{Authors' contribution}

A. Stolzing, Y. Naaldijk, A. Hinze and C. Jaeger were responsible for study design and transplantation overview and A. Stolzing for the idea. Y. Naaldijk, C. Jaeger, L. Rudolph, A. Hinze and C. Fabian carried out bone marrow isolation, MSC cultivation, transplantations, perfusion, brain and organ preparation, histology staining and microscopic analysis. C. Fabian confirmed the genotypic identity of the animals. A. Blüher performed staining and microscopy analysis. C. Jaeger carried out Laser scanning microscopy. A. Stolzing was responsible for designs of graphs, data analysis, budget acquisition, manuscript writing and final approval. C. Fabian was involved in PCR primer design, organ \& DNA isolation, analysis and PCR data summary. C. Leovsky isolated DNA and performed PCR analysis. Y. Naaldijk, C. Leovsky, C. Fabian, C. Jaeger and A. Hinze helped with manuscript writing.

\section{Conflict of interest}

None.

\section{Acknowledgements}

The work presented in this paper was made possible by funding from the German Federal Ministry of Education and Research (BMBF 1315883), Fraunhofer Society and Dan Stoicescu as well as Longecity funding. We thank Dr. Markus Morawski from the Paul Flechsig Institute for Brain research for providing eGFP transgenic mice as bone marrow donors. Special thanks for Dr. Sebastian Sethe for comments and critical reading.

\section{Legends}

Figure 1. Migration of transplanted mesenchymal stem cells into the brain of APP/PS1 mice. Intravenously transplanted $\mathrm{eGFP}^{+}-\mathrm{MSC}$ s were able to migrate into the brain parenchyma. eGFP+-MSCs (Anti-GFP; green) were found associated with activated microglia (Iba-1; red) but not showing IBA-1 immunoreactivity. Lower row, right picture: Overlay with orthoview based on stack analysis, supplemented by nuclei staining (DAPI, blue).

This article is protected by copyright. All rights reserved. 
Figure 2. Transplanted mesenchymal stem cells alleviate $p E 3-A \beta$ plaque size in brains of APP/PS1 mice (A) Brain sections from control animals and MSC treated AD mice stained for anti-pE3-A $\beta$ (control group, d7, d28). Cortex and hippocampus areas were analysed and the level of $p E 3-A \beta$ plaque size for the cortex $(B)$ and hippocampus $(C)$ areas was quantified at day 28.Small, middle and large $p E 3-A B$ plaques are shown exemplarily below. Data is representative as mean \pm SEM for BM-MSC $(n=4)$ and $\mathrm{NaCl}(n=5)$. Statistical significances are represented as ${ }^{*} p<0.05,{ }^{* *} p<0.01$ and ${ }^{* * *} p<0.001$.

Figure 3. $p E 3-A \beta$ plaque size at day 7 and distribution and presence of $p E 3-A \beta$ on vessels and in astrocytes after MSC transplantation. (A) Analysis of $p E 3-A \beta$ plaque size for the cortex and hippocampus at day 7 after transplantation. Presence of $p E 3-A \beta$ in vessels (B) and astrocytes (C) shown after transplantation. Red arrows indicate the presence of $p E 3-A \beta$ in veins and $p E 3-A \beta$ in astrocytes and black arrows show the amyloid plaques. Data is representative as mean \pm SEM for BM-MSC $(n=3)$ and $\mathrm{NaCl}(n=3)$.

Figure 4. BM-MSC trigger activation of microglia cells in cortex and hippocampus in the brain of APP/PS1 mice. (A) Brain sections stained for lba-1 in APP/PS1 mice transplanted with MSC or $\mathrm{NaCl}$. (B) Quantitative stereological analysis for microglia (Iba-1) number in the cortex and hippocampus of APP/PS1 mice transplanted with MSC or $\mathrm{NaCl}$. (C) Representative pictures of microglia distribution and morphology for cortex and hippocampus area. (D) Quantitative analysis of microglia activation on the basis of microglia size. Data is representative as mean \pm SEM for BM-MSC $(n=4)$ and $\mathrm{NaCl}(n=5)$. Statistical significances are represented as ${ }^{*} p<0.05,{ }^{* *} p<0.01$ and ${ }^{* * *} p<0.001$.

Figure 5. Treatment with BM-MSC resulted in changed levels in growth factors, inflammation and migration markers after transplantation in the cortex of APP/PS1 mice. mRNA expression of chemoattractant MCP-1\& CCR5, growth factors NGF\& BDNF and inflammation markers PTGER2, TGF- $\beta$, TNF- $\alpha$, and IL- 6 in cortex of APP/PS1 which received either BM-MSC $(n=3)$ or $\mathrm{NaCl}(n=5)$. Most markers showed a clear decrease in MSC-treated animals compared to the control group; however IL-6 and BDNF revealed an increase. Values were normalized to 36B4 level. Data is represented as mean \pm SD. Statistical significances are represented as ${ }^{*} p<0.05,{ }^{* *} p<0.01$ and ${ }^{* * *} p<0.001$.

Figure 6. BM-MSC resulted in changed levels of inflammation markers after transplantation in the hippocampus of APP/PS1 mice. mRNA expression of chemoattractant MCP-1 \& CCR5, growth factors NGF \& BDNF \& VEGF-A and inflammation 
markers PTGER2, TNF- $\alpha$, IFN- $\gamma$, IL-10 and IL-6 in hippocampus of APP/PS1 which received either BM-MSC $(n=3)$ or $\mathrm{NaCl}(n=5)$. Most markers showed a clear down-regulation in MSCtreated animals compared to the control group; however PTGER, IL-10 and CCR5 revealed an increase. Values were normalized to 36B4 level. Data is represented as mean \pm SD. Statistical significances are represented as ${ }^{*} p<0.05,{ }^{* *} p<0.01$ and ${ }^{* * *} p<0.001$.

\section{Supplementary Figure 1. Stereological analysis of $\mathrm{pE3}-\mathrm{AB}$ plaques in MSC-treated} APP/PS1 mice vs. controls (NaCl). $p E 3-A ß$ plaque numbers in the cortex and hippocampus of BM-MSC treated APP/PS1 mice compared to the control group at day 7 (A) for BM-MSC $(n=3)$ and $\mathrm{NaCl}(n=3)$ and day $28(B)$ for BM-MSC $(n=4)$ and $\mathrm{NaCl}(n=5)$ posttransplantation. Data is representative as mean \pm SEM.

Supplementary Figure 2. Analysis of Thioflavin S covered area in MSC-treated APP/PS1 mice vs. controls ( $\mathrm{NaCl})$. Thioflavin $\mathrm{S}$ covered area was analysed on day 7 and day 28 after MSC transplantation. Data is representative as mean \pm SEM for BM-MSC $(n=3$ (d7) and $\mathrm{n}=4(\mathrm{~d} 28))$ and $\mathrm{NaCl}(\mathrm{n}=3(\mathrm{~d} 7)$ and $\mathrm{n}=5(\mathrm{~d} 28))$. Statistical significances are represented as ${ }^{*} p<0.05,{ }^{* *} p<0.01$ and ${ }^{* * *} p<0.001$

Supplementary Figure 3. Effect of MSC transplantation on microglia activation in cortex and hippocampus in the brain of APP/PS1 mice at day 7. (A) Microglia distribution in MSC-treated APP/PS1 mice vs. control ( $\mathrm{NaCl})$. (B) Stereological analysis of microglia numbers in the cortex and hippocampus at day 7. (C) Representative distribution and morphology of lba-1 positive cells in the cortex and hippocampus for MSC-treated APP/PS1 mice vs. controls $(\mathrm{NaCl})$ at day 7. (D) Analysis of activated microglia by measurement of IBA-1 covered area for MSC-treated APP/PS1 mice vs. controls ( $\mathrm{NaCl}$ ) at day 7. Data is shown representative as mean \pm SEM for BM-MSC $(n=3)$ and $\mathrm{NaCl}(n=3)$.

Supplementary Figure 4. Effect of MSC transplantation on astrocyte activation in cortex and hippocampus in the brain of APP/PS1 mice at day 7. Analysis of activated astrocytes by measuring GFAP-covered area for the cortex (A) and hippocampus (B) after MSC transplantation vs. controls $(\mathrm{NaCl})$. Data is representative as mean \pm SEM for BM-MSC $(\mathrm{n}=3-4)$ and $\mathrm{NaCl}(\mathrm{n}=8)$.

Supplementary Figure 5. Presence of transplanted GFP-MSC around amyloid plaques. Intravenously transplanted eGFP ${ }^{+}$-MSCs were able to migrate into the brain parenchyma. 
eGFP ${ }^{+}$-MSCs (Anti-GFP; green) were found associated with activated microglia (lba-1; red) but not showing IBA-1 immunoreactivity. Nuclei were stained with DAPI (blue). Pictures were taken with a Zeiss confocal microscope at $40 x$ magnification.

Supplementary Figure 6. MSC characterisation. In vitro differentiation of BM-MSC under adipogenic $(A)$, osteogenic $(B)$ or chondrogenic $(C)$ conditions. Differentiation was verified by qualitative analysis: Adipogenesis was shown by staining lipid vesicles with Oil Red-O $(A)$, osteogenesis was shown by staining alkaline phosphatase with Fast Red (B) and chondrogenesis was shown by staining sulphated proteoglycans typical for extracellular matrix composition with Alcian Blue under acidic conditions.

Supplementary Figure 7. MSC characterisation. BM-MSC were analysed using FACS staining. MSC were stained with DIO and DIL (positive controls for FL1 and FL2) and IgG as negative control. MSC were found to be negative for CD11b and CD45 and positive for CD44, CD90, CD105 and CD133.

Table 1. Primer sequences used for qPCR

\begin{tabular}{|c|c|c|c|c|}
\hline Name & Gene & Sense primer [5'-3'] & Antisense primer [5'-3'] & $\begin{array}{l}\text { NCBI } \\
\text { accessio } \\
\text { n number }\end{array}$ \\
\hline 36B4 & $\begin{array}{l}\text { ribosomal } \\
\text { protein large } \\
\text { P0 RPLP0 }\end{array}$ & $\begin{array}{l}\text { CCGTGTGAGGTCACT } \\
\text { GTGCCAGCTC }\end{array}$ & $\begin{array}{l}\text { GCCCAAAGCCTGGAA } \\
\text { GAAGGAGGTC }\end{array}$ & $\begin{array}{l}\text { NM_0074 } \\
75 . \overline{5}\end{array}$ \\
\hline IL-6 & interleukin 6 & $\begin{array}{l}\text { CCAGTTGCCTTCTTGG } \\
\text { GACTGATG }\end{array}$ & $\begin{array}{l}\text { CCGGACTTGTGAAGTA } \\
\text { GGGAAGGC }\end{array}$ & $\begin{array}{l}\text { NM_0311 } \\
68.1\end{array}$ \\
\hline TNF- $\alpha$ & $\begin{array}{l}\text { tumor } \\
\text { necrosis } \\
\text { factor }\end{array}$ & $\begin{array}{l}\text { GACAGCAAGGGACTA } \\
\text { GCCAGGAGGG }\end{array}$ & $\begin{array}{l}\text { GGGAGTGCCTCTTCT } \\
\text { GCCAGTTCC }\end{array}$ & $\begin{array}{l}\text { NM_0136 } \\
93.2\end{array}$ \\
\hline MCP-1 & $\begin{array}{l}\text { transcription } \\
\text { regulatory } \\
\text { protein MCP- } \\
1 \text { (POU 1) }\end{array}$ & $\begin{array}{l}\text { GCAGTAATCCTCACCA } \\
\text { GCCCAACGC }\end{array}$ & $\begin{array}{l}\text { GATCCCGTCCTCATCC } \\
\text { AGACTTGG }\end{array}$ & L13763.1 \\
\hline $\begin{array}{l}\text { PTGE } \\
\text { R2 }\end{array}$ & $\begin{array}{l}\text { Prostaglandi } \\
\text { n E2 receptor } \\
\text { subtype } 2\end{array}$ & $\begin{array}{l}\text { CGGCACGGGAGGACT } \\
\text { GCATACCTTC }\end{array}$ & $\begin{array}{l}\text { GCAGCGGCTTCTTCTG } \\
\text { CTCCGACG }\end{array}$ & $\begin{array}{l}\text { NM_0089 } \\
64.4\end{array}$ \\
\hline $\begin{array}{l}\text { VEGF- } \\
\text { A }\end{array}$ & $\begin{array}{l}\text { vascular } \\
\text { endothelial } \\
\text { growth factor } \\
\text { A }\end{array}$ & $\begin{array}{l}\text { CCGGAGGGCGAGACT } \\
\text { CCG }\end{array}$ & $\begin{array}{l}\text { GTGGGTGTGTCTACA } \\
\text { GGAATCCCAG }\end{array}$ & $\begin{array}{l}\text { NM_0010 } \\
25250.3\end{array}$ \\
\hline NGF & $\begin{array}{l}\text { nerve growth } \\
\text { factor }\end{array}$ & $\begin{array}{l}\text { GGCTGGATGGCATGC } \\
\text { TGGACCC }\end{array}$ & $\begin{array}{l}\text { GTACGGTTCTGCCTGT } \\
\text { ACGCCGATC }\end{array}$ & $\begin{array}{l}\text { NM_0136 } \\
09 . \overline{2}\end{array}$ \\
\hline
\end{tabular}

This article is protected by copyright. All rights reserved. 


\begin{tabular}{|c|c|c|c|c|}
\hline & $\begin{array}{l}\text { transcript } \\
\text { variant } A\end{array}$ & & & \\
\hline IFN-y & $\begin{array}{l}\text { interferon } \\
\text { gamma }\end{array}$ & $\begin{array}{l}\text { CCCACAGGTCCAGCG } \\
\text { CCAAGCA }\end{array}$ & $\begin{array}{l}\text { CCGCTTCCTGAGGCT } \\
\text { GGATTCCG }\end{array}$ & $\begin{array}{l}\text { NM_0083 } \\
37.3\end{array}$ \\
\hline IL-10 & Interleukin 10 & $\begin{array}{l}\text { CATGCCTGGCTCAGC } \\
\text { ACTGCTATGC }\end{array}$ & $\begin{array}{l}\text { CTGGCCGACTGGGAA } \\
\text { GTGGGTGCAG }\end{array}$ & $\begin{array}{l}\text { NM_0105 } \\
48.2\end{array}$ \\
\hline CCR5 & $\begin{array}{l}\text { chemokine } \\
\text { (C-C motif) } \\
\text { receptor } 5\end{array}$ & $\begin{array}{l}\text { CGGGTATAGACTGAG } \\
\text { CTTGCACGATC }\end{array}$ & $\begin{array}{l}\text { CCGAAAACACATGGTC } \\
\text { AAACGCTT }\end{array}$ & $\begin{array}{l}\text { NM_0099 } \\
17.5\end{array}$ \\
\hline BDNF & $\begin{array}{l}\text { Brain derived } \\
\text { neurotrophic } \\
\text { factor }\end{array}$ & $\begin{array}{l}\text { CGTCCACGGACAAGG } \\
\text { CAACTTG }\end{array}$ & $\begin{array}{l}\text { CCGAACCTTCTGGTCC } \\
\text { TCATCCA }\end{array}$ & $\begin{array}{l}\text { NM_0075 } \\
40.4\end{array}$ \\
\hline
\end{tabular}

\section{References}

1. Bekris LM, Yu CE, Bird TD, Tsuang DW. Genetics of Alzheimer disease. J Geriatr Psychiatry Neurol. 2010;23(4):213-27.

2. Cagnin A, Brooks DJ, Kennedy AM, Gunn RN, Myers R, Turkheimer FE, Jones T, Banati RB. In-vivo measurement of activated microglia in dementia. Lancet. $2001 ; 358(9280): 461-7$.

3. Xiang Z, Haroutunian V, Ho L, Purohit D, Pasinetti GM. Microglia activation in the brain as inflammatory biomarker of Alzheimer's disease neuropathology and clinical dementia. Dis Markers. 2006;22(1-2):95-102.

4. Streit WJ, Braak H, Xue QS, Bechmann I. Dystrophic (senescent) rather than activated microglial cells are associated with tau pathology and likely precede neurodegeneration in Alzheimer's disease. Acta Neuropathol. 2009;118(4):475-85.

5. Luo XG, Chen SD. The changing phenotype of microglia from homeostasis to disease. Transl Neurodegener. 2012;1(1):9.

6. Babaei $\mathrm{P}$, Soltani Tehrani B, Alizadeh A. Transplanted bone marrow mesenchymal stem cells improve memory in rat models of Alzheimer's disease. Stem Cells Int. 2012;2012:369417.

7. Kim KS, Kim HS, Park JM, Kim HW, Park MK, Lee HS, Lim DS, Lee TH, Chopp M, Moon J. Long-term immunomodulatory effect of amniotic stem cells in an Alzheimer's disease model. Neurobiol Aging. 2013;34(10):2408-20.

8. Yang $\mathrm{H}$, Yue $\mathrm{C}$, Xie $\mathrm{Z}$, Hu H, Wei L, Wang $\mathrm{P}$, Zhao $\mathrm{C}$, Bi J. Intravenous Administration of Human Umbilical Cord Mesenchymal Stem Cells Improves Cognitive Impairments and Reduces Amyloid-Beta Deposition in an AßPP/PS1 Transgenic Mouse Model. Neurochem Res. 2013.

9. Hanisch UK, Kettenmann $\mathrm{H}$. Microglia: active sensor and versatile effector cells in the normal and pathologic brain. Nat Neurosci. 2007;10(11):1387-94.

10. Dheen ST, Kaur C, Ling EA. Microglial activation and its implications in the brain diseases. Curr Med Chem. 2007;14(11):1189-97.

11. Perry VH, Teeling J. Microglia and macrophages of the central nervous system: the contribution of microglia priming and systemic inflammation to chronic neurodegeneration. Semin Immunopathol. 2013;35(5):601-12.

12. Block ML, Hong JS. Microglia and inflammation-mediated neurodegeneration: multiple triggers with a common mechanism. Prog Neurobiol. 2005;76(2):77-98.

This article is protected by copyright. All rights reserved. 
13. Peterson PK, Hu S, Salak-Johnson J, Molitor TW, Chao CC. Differential production of and migratory response to beta chemokines by human microglia and astrocytes. J Infect Dis. 1997;175(2):478-81.

14. McManus CM, Brosnan CF, Berman JW. Cytokine induction of MIP-1 alpha and MIP1 beta in human fetal microglia. J Immunol. 1998;160(3):1449-55.

15. Cho H, Hashimoto T, Wong E, Hori Y, Wood LB, Zhao L, Haigis KM, Hyman BT, Irimia D. Microfluidic chemotaxis platform for differentiating the roles of soluble and bound amyloid- $\beta$ on microglial accumulation. Sci Rep. 2013;3:1823.

16. Lee JK, Schuchman EH, Jin HK, Bae JS. Soluble CCL5 derived from bone marrowderived mesenchymal stem cells and activated by amyloid $\beta$ ameliorates Alzheimer's disease in mice by recruiting bone marrow-induced microglia immune responses. Stem Cells. 2012;30(7):1544-55.

17. Lee HJ, Lee JK, Lee H, Carter JE, Chang JW, Oh W, Yang YS, Suh JG, Lee BH, Jin $\mathrm{H}$ K, Bae JS. Human umbilical cord blood-derived mesenchymal stem cells improve neuropathology and cognitive impairment in an Alzheimer's disease mouse model through modulation of neuroinflammation. Neurobiol Aging. 2012;33(3):588-602.

18. Malm TM, Koistinaho M, Pärepalo M, Vatanen T, Ooka A, Karlsson S, Koistinaho J. Bone-marrow-derived cells contribute to the recruitment of microglial cells in response to beta-amyloid deposition in APP/PS1 double transgenic Alzheimer mice. Neurobiol Dis. 2005;18(1):134-42.

19. Radde R, Bolmont T, Kaeser SA, Coomaraswamy J, Lindau D, Stoltze L, Calhoun ME, Jaggi F, Wolburg H, Gengler S, Haass C, Ghetti B, Czech C, Holscher C, Mathews PM, Jucker M. Abeta42-driven cerebral amyloidosis in transgenic mice reveals early and robust pathology. EMBO Rep. 2006;7(9):940-6.

20. Dobson KR, Reading L, Haberey M, Marine X, Scutt A. Centrifugal isolation of bone marrow from bone: an improved method for the recovery and quantitation of bone marrow osteoprogenitor cells from rat tibiae and femurae. Calcif Tissue Int. 1999;65(5):411-3.

21. Sekiya I, Larson BL, Smith JR, Pochampally R, Cui JG, Prockop DJ. Expansion of human adult stem cells from bone marrow stroma: conditions that maximize the yields of early progenitors and evaluate their quality. Stem Cells. 2002;20(6):530-41.

22. Streit WJ. Microglia and Alzheimer's disease pathogenesis. J Neurosci Res. 2004;77(1):1-8.

23. Griffin WS. Inflammation and neurodegenerative diseases. Am J Clin Nutr. 2006;83(2):470S-4S.

24. Ha S, Ahn S, Kim S, Joo Y, Chong YH, Suh YH, Chang KA. In vivo imaging of human adipose-derived stem cells in Alzheimer's disease animal model. J Biomed Opt. 2014;19(5):051206.

25. Stemberger S, Jamnig A, Stefanova N, Lepperdinger G, Reindl M, Wenning GK. Mesenchymal stem cells in a transgenic mouse model of multiple system atrophy: immunomodulation and neuroprotection. PLoS One. 2011;6(5):e19808.

26. Lee JK, Jin HK, Endo S, Schuchman EH, Carter JE, Bae JS. Intracerebral transplantation of bone marrow-derived mesenchymal stem cells reduces amyloid-beta deposition and rescues memory deficits in Alzheimer's disease mice by modulation of immune responses. Stem Cells. 2010;28(2):329-43.

27. Lee JK, Jin HK, Bae JS. Bone marrow-derived mesenchymal stem cells attenuate amyloid $\beta$-induced memory impairment and apoptosis by inhibiting neuronal cell death. Curr Alzheimer Res. 2010;7(6):540-8.

28. Lee JK, Jin HK, Bae JS. Bone marrow-derived mesenchymal stem cells reduce brain amyloid-beta deposition and accelerate the activation of microglia in an acutely induced Alzheimer's disease mouse model. Neurosci Lett. 2009;450(2):136-41.

This article is protected by copyright. All rights reserved. 
29. Ma T, Gong K, Ao Q, Yan Y, Song B, Huang H, Zhang X, Gong Y Intracerebral transplantation of adipose-derived mesenchymal stem cells alternatively activates microglia and ameliorates neuropathological deficits in Alzheimer's disease mice. Cell Transplant. 2013;22 Suppl 1:S113-26.

30. Nikolic WV, Hou H, Town T, Zhu Y, Giunta B, Sanberg CD, Zeng J, Luo D, Ehrhart J, Mori T, Sanberg PR, Tan J. Peripherally administered human umbilical cord blood cells reduce parenchymal and vascular beta-amyloid deposits in Alzheimer mice. Stem Cells Dev. 2008;17(3):423-39.

31. Kim S, Chang KA, Kim J, Park HG, Ra JC, Kim HS, Suh YH. The preventive and therapeutic effects of intravenous human adipose-derived stem cells in Alzheimer's disease mice. PLoS One. 2012;7(9):e45757.

32. Yang H, Xie Z, Wei L, Bi J. Systemic transplantation of human umbilical cord derived mesenchymal stem cells-educated $T$ regulatory cells improved the impaired cognition in AßPPswe/PS1dE9 transgenic mice. PLoS One. 2013;8(7):e69129.

33. Akiyama H, Arai $\mathrm{T}$, Kondo $\mathrm{H}$, Tanno E, Haga C, lkeda K. Cell mediators of inflammation in the Alzheimer disease brain. Alzheimer Dis Assoc Disord. 2000;14 Suppl $1:$ S47-53.

34. Rubio-Perez JM, Morillas-Ruiz JM. A review: inflammatory process in Alzheimer's disease, role of cytokines. ScientificWorldJournal. 2012;2012:756357.

35. Fillit H, Ding WH, Buee L, Kalman J, Altstiel L, Lawlor B, Wolf-Klein G. Elevated circulating tumor necrosis factor levels in Alzheimer's disease. Neurosci Lett. 1991;129(2):318-20.

36. Perry RT, Collins JS, Wiener H, Acton R, Go RC. The role of TNF and its receptors in Alzheimer's disease. Neurobiol Aging. 2001;22(6):873-83.

37. Janelsins MC, Mastrangelo MA, Oddo S, LaFerla FM, Federoff HJ, Bowers WJ. Early correlation of microglial activation with enhanced tumor necrosis factor-alpha and monocyte chemoattractant protein-1 expression specifically within the entorhinal cortex of triple transgenic Alzheimer's disease mice. J Neuroinflammation. 2005;2:23.

38. Oddo S, Caccamo A, Shepherd JD, Murphy MP, Golde TE, Kayed R, Metherate R, Mattson MP, Akbari Y, LaFerla FM. Triple-transgenic model of Alzheimer's disease with plaques and tangles: intracellular Abeta and synaptic dysfunction. Neuron. 2003;39(3):40921.

39. Billings LM, Oddo S, Green KN, McGaugh JL, LaFerla FM. Intraneuronal Abeta causes the onset of early Alzheimer's disease-related cognitive deficits in transgenic mice. Neuron. 2005;45(5):675-88.

40. Janelsins MC, Mastrangelo MA, Park KM, Sudol KL, Narrow WC, Oddo S, LaFerla FM, Callahan LM, Federoff HJ, Bowers WJ. Chronic neuron-specific tumor necrosis factoralpha expression enhances the local inflammatory environment ultimately leading to neuronal death in 3xTg-AD mice. Am J Pathol. 2008;173(6):1768-82.

41. Chavant F, Deguil J, Pain S, Ingrand I, Milin S, Fauconneau B, Perault-Pochat MC, Lafay-Chebassier C. Imipramine, in part through tumor necrosis factor alpha inhibition, prevents cognitive decline and beta-amyloid accumulation in a mouse model of Alzheimer's disease. J Pharmacol Exp Ther. 2010;332(2):505-14.

42. Yang $\mathrm{H}$, Xie Z, Wei L, Yang $\mathrm{H}$, Yang $\mathrm{S}$, Zhu Z, Wang $\mathrm{P}$, Zhao C, Bi J. Human umbilical cord mesenchymal stem cell-derived neuron-like cells rescue memory deficits and reduce amyloid-beta deposition in an ABPP/PS1 transgenic mouse model. Stem Cell Res Ther. 2013;4(4):76.

43. Lee HJ, Lee JK, Lee H, Shin JW, Carter JE, Sakamoto T, Jin HK, Bae JS. The therapeutic potential of human umbilical cord blood-derived mesenchymal stem cells in Alzheimer's disease. Neurosci Lett. 2010;481(1):30-5.

This article is protected by copyright. All rights reserved. 
44. Fahnestock M, Michalski B, Xu B, Coughlin MD. The precursor pro-nerve growth factor is the predominant form of nerve growth factor in brain and is increased in Alzheimer's disease. Mol Cell Neurosci. 2001;18(2):210-20.

45. Pedraza CE, Podlesniy P, Vidal N, Arévalo JC, Lee R, Hempstead B, Ferrer I, Iglesias $\mathrm{M}$, Espinet $\mathrm{C}$. Pro-NGF isolated from the human brain affected by Alzheimer's disease induces neuronal apoptosis mediated by p75NTR. Am J Pathol. 2005;166(2):53343.

46. Podlesniy P, Kichev A, Pedraza C, Saurat J, Encinas M, Perez B, Ferrer I, Espinet C. Pro-NGF from Alzheimer's disease and normal human brain displays distinctive abilities to induce processing and nuclear translocation of intracellular domain of p75NTR and apoptosis. Am J Pathol. 2006;169(1):119-31.

47. Al-Shawi R, Hafner A, Chun S, Raza S, Crutcher K, Thrasivoulou C, Simons P, Cowen T. ProNGF, sortilin, and age-related neurodegeneration. Ann N Y Acad Sci. 2007;1119:208-15.

48. Perry EK, Tomlinson BE, Blessed G, Bergmann K, Gibson PH, Perry RH. Correlation of cholinergic abnormalities with senile plaques and mental test scores in senile dementia. Br Med J. 1978;2(6150):1457-9.

49. Mufson EJ, Counts SE, Perez SE, Ginsberg SD. Cholinergic system during the progression of Alzheimer's disease: therapeutic implications. Expert Rev Neurother. 2008;8(11):1703-18.

50. Duan L, Chen BY, Sun XL, Luo ZJ, Rao ZR, Wang JJ, Chen LW. LPS-induced proNGF synthesis and release in the $\mathrm{N} 9$ and BV2 microglial cells: a new pathway underling microglial toxicity in neuroinflammation. PLoS One. 2013;8(9):e73768.

51. Kichev A, Ilieva EV, Pinol-Ripoll G, Podlesniy P, Ferrer I, Portero-Otin M, Pamplona $R$, Espinet $C$. Cell death and learning impairment in mice caused by in vitro modified proNGF can be related to its increased oxidative modifications in Alzheimer disease. Am J Pathol. 2009;175(6):2574-85.

52. Montine TJ, Sidell KR, Crews BC, Markesbery WR, Marnett LJ, Roberts LJ, 2nd, Morrow JD. Elevated CSF prostaglandin E2 levels in patients with probable AD. Neurology. 1999;53(7):1495-8.

53. Liang X, Wang Q, Hand T, Wu L, Breyer RM, Montine TJ, Andreasson K. Deletion of the prostaglandin E2 EP2 receptor reduces oxidative damage and amyloid burden in a model of Alzheimer's disease. J Neurosci. 2005;25(44):10180-7.

54. Wei LL, Shen YD, Zhang YC, Hu XY, Lu PL, Wang L, Chen W. Roles of the prostaglandin E2 receptors EP subtypes in Alzheimer's disease. Neurosci Bull. 2010;26(1):77-84.

55. Yang $\mathrm{H}$, Zhang J, Breyer RM, Chen C. Altered hippocampal long-term synaptic plasticity in mice deficient in the PGE2 EP2 receptor. J Neurochem. 2009;108(1):295-304.

56. Sokolova A, Hill MD, Rahimi F, Warden LA, Halliday GM, Shepherd CE. Monocyte chemoattractant protein-1 plays a dominant role in the chronic inflammation observed in Alzheimer's disease. Brain Pathol. 2009;19(3):392-8.

57. Kim JY, Kim DH, Kim JH, Lee D, Jeon HB, Kwon SJ, Kim SM, Yoo YJ, Lee EH, Choi SJ, Seo SW, Lee JI, Na DL, Yang YS, Oh W, Chang JW. Soluble intracellular adhesion molecule-1 secreted by human umbilical cord blood-derived mesenchymal stem cell reduces amyloid- $\beta$ plaques. Cell Death Differ. 2012;19(4):680-91.

58. Boche D, Perry VH, Nicoll JA. Review: activation patterns of microglia and their identification in the human brain. Neuropathol Appl Neurobiol. 2013;39(1):3-18.

59. El Khoury J, Luster AD. Mechanisms of microglia accumulation in Alzheimer's disease: therapeutic implications. Trends Pharmacol Sci. 2008;29(12):626-32.

This article is protected by copyright. All rights reserved. 
60. Kozlowski C, Weimer RM. An automated method to quantify microglia morphology and application to monitor activation state longitudinally in vivo. PLoS One. 2012;7(2):e31814.

This article is protected by copyright. All rights reserved. 
Residentmicrogla and immigrated GPP+ MSC 28 days after transplantation
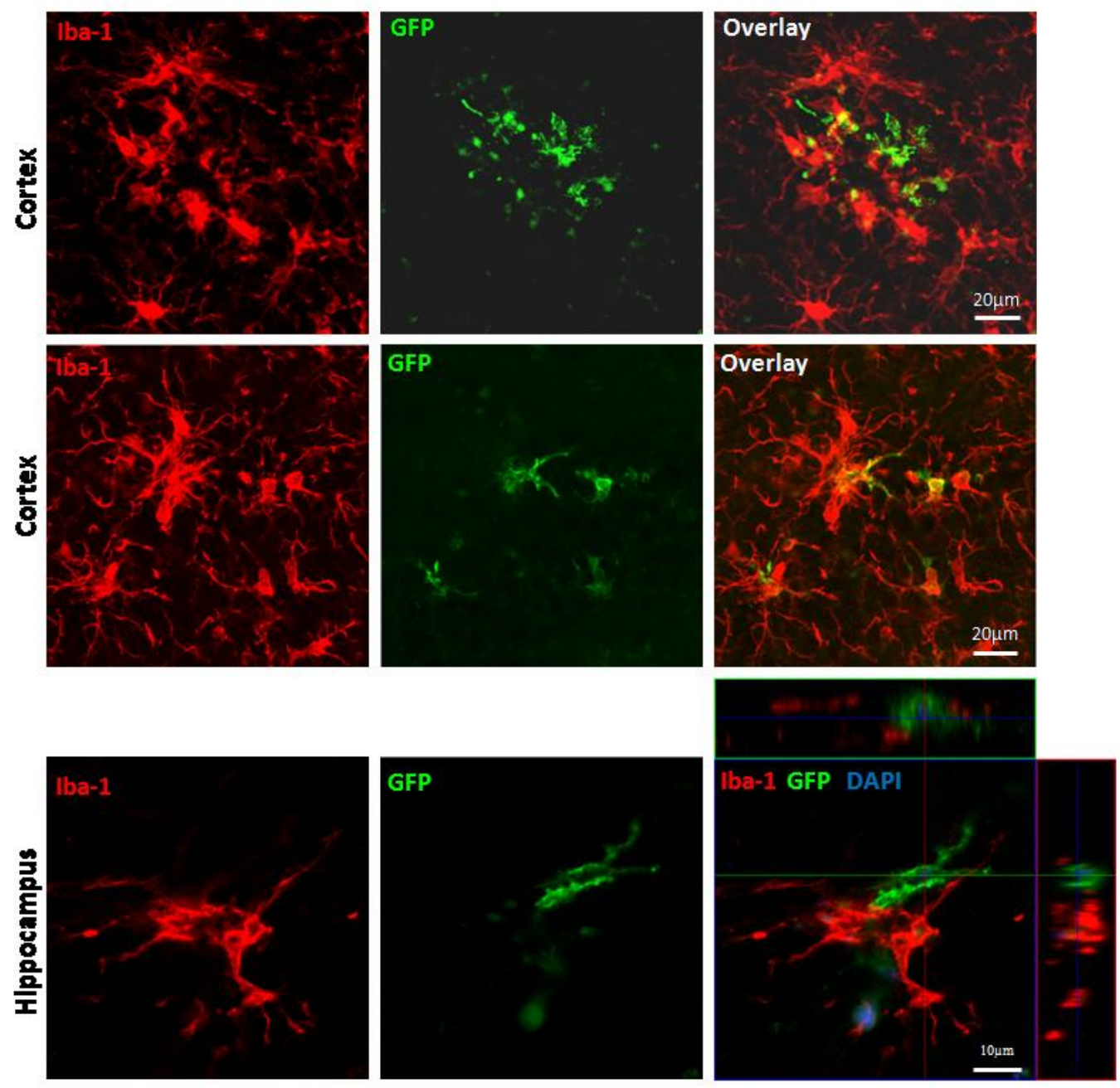

Figure 1

This article is protected by copyright. All rights reserved. 
A. Amyloid plaque distribution after MSC transplantation

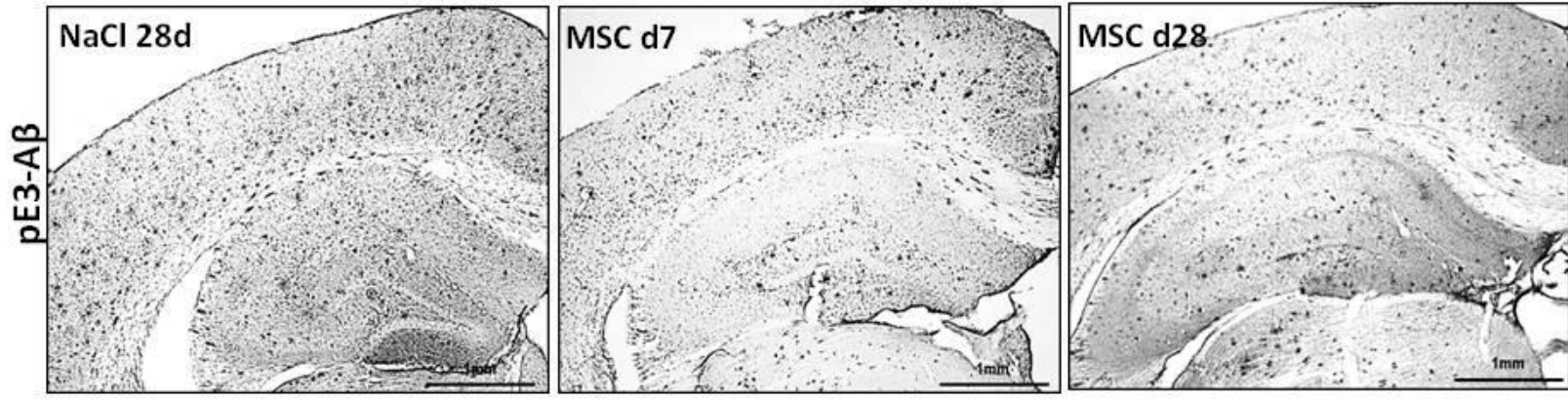

B. Amyloid plaque size - Cortex d28
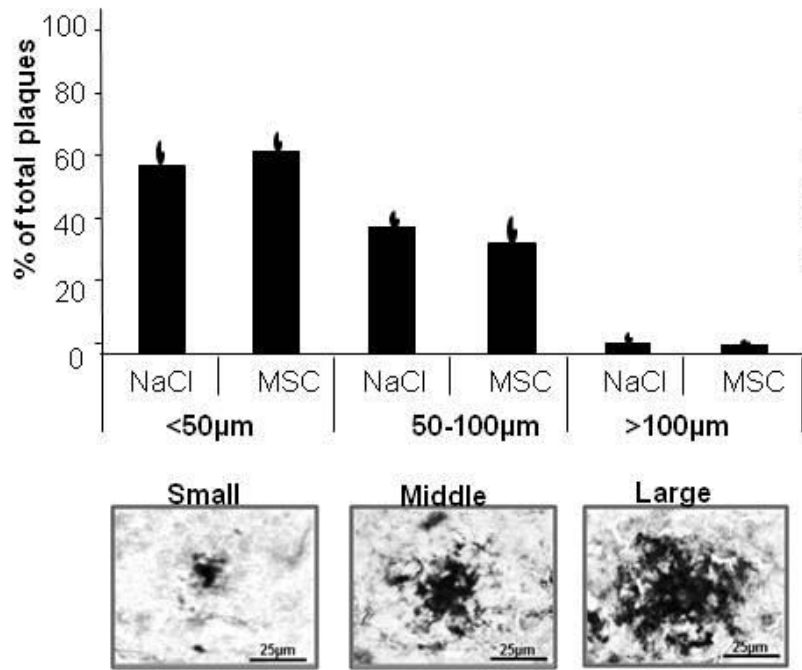

C. Amyloid plaque size-Hippocampus d28

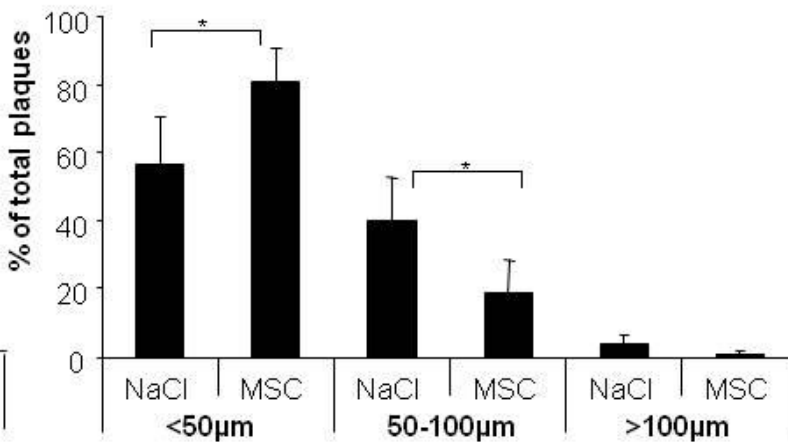

Figure 2

This article is protected by copyright. All rights reserved. 
A. Amyloid plaque size $-\mathrm{d} 7$

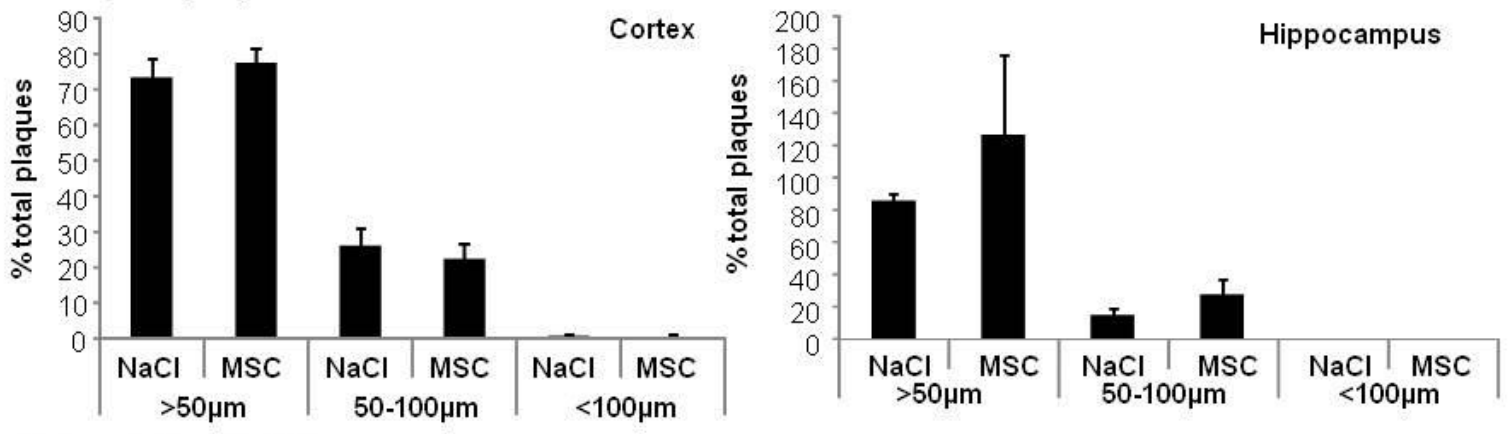

B. Amyloid $p E 3-A \beta$ in vessels
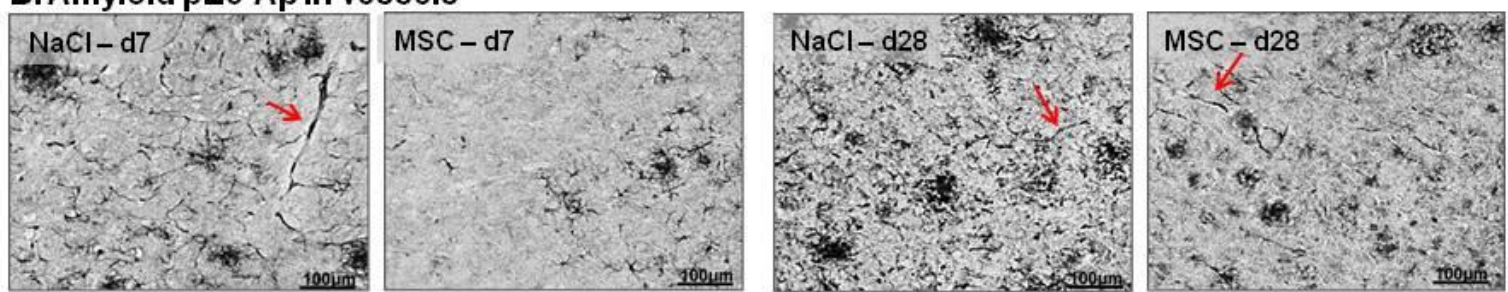

C. Amyloid pE3-A $\beta$ in astrocytes
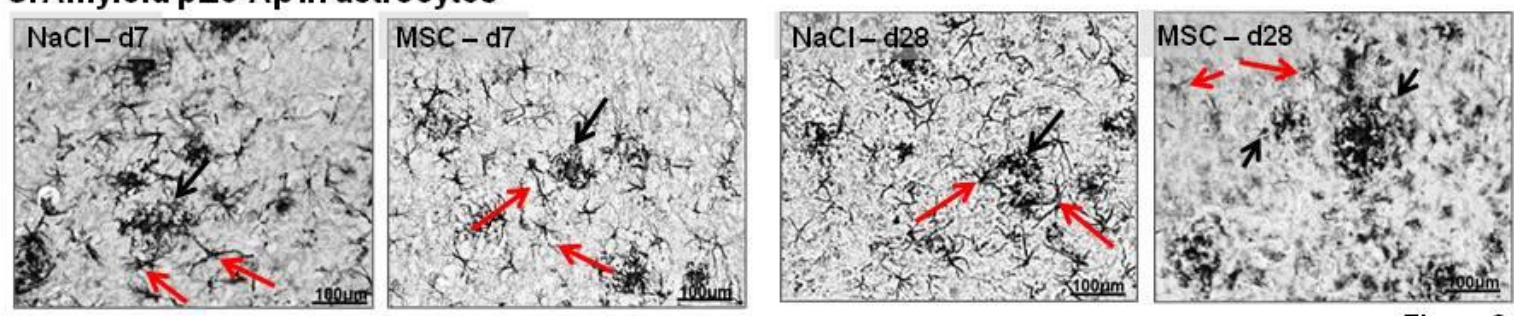

Figure 3

This article is protected by copyright. All rights reserved. 


\section{A. Microglia distribution}
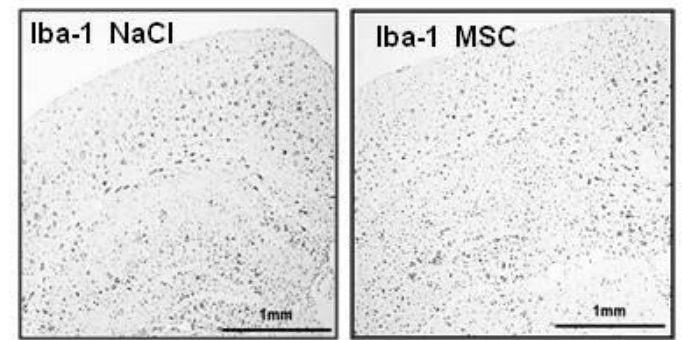

\section{Microglia morphology}
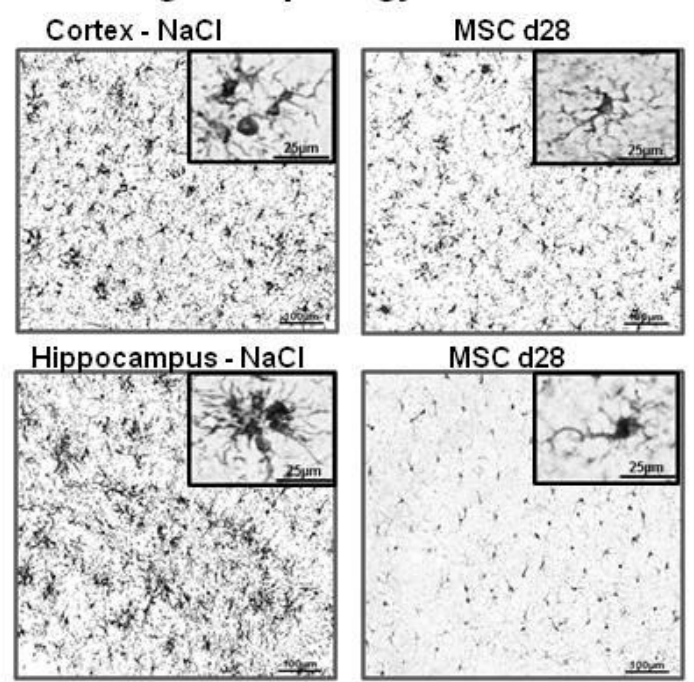

\section{B. Microglia number}
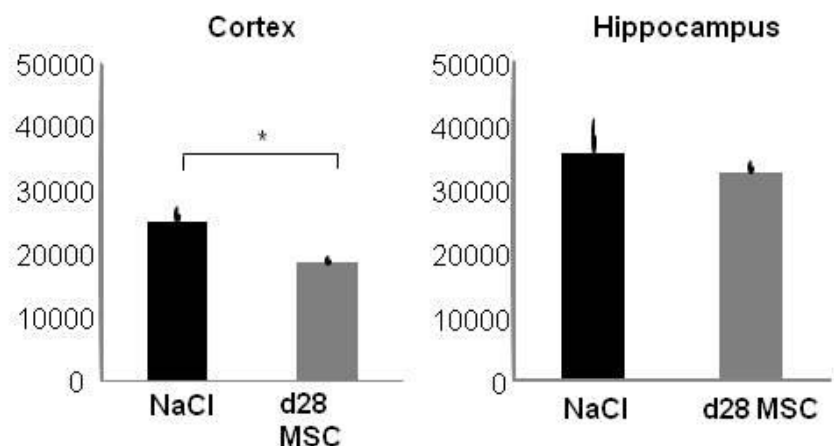

\section{Microglia size}

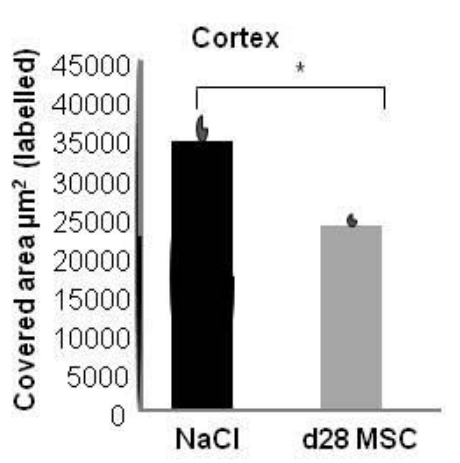

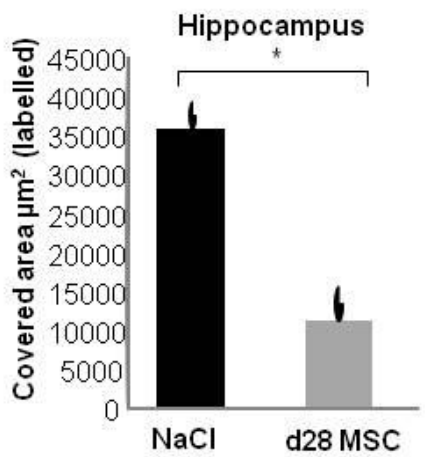

Figure 4

This article is protected by copyright. All rights reserved. 
Gene expression in cortex on day 28
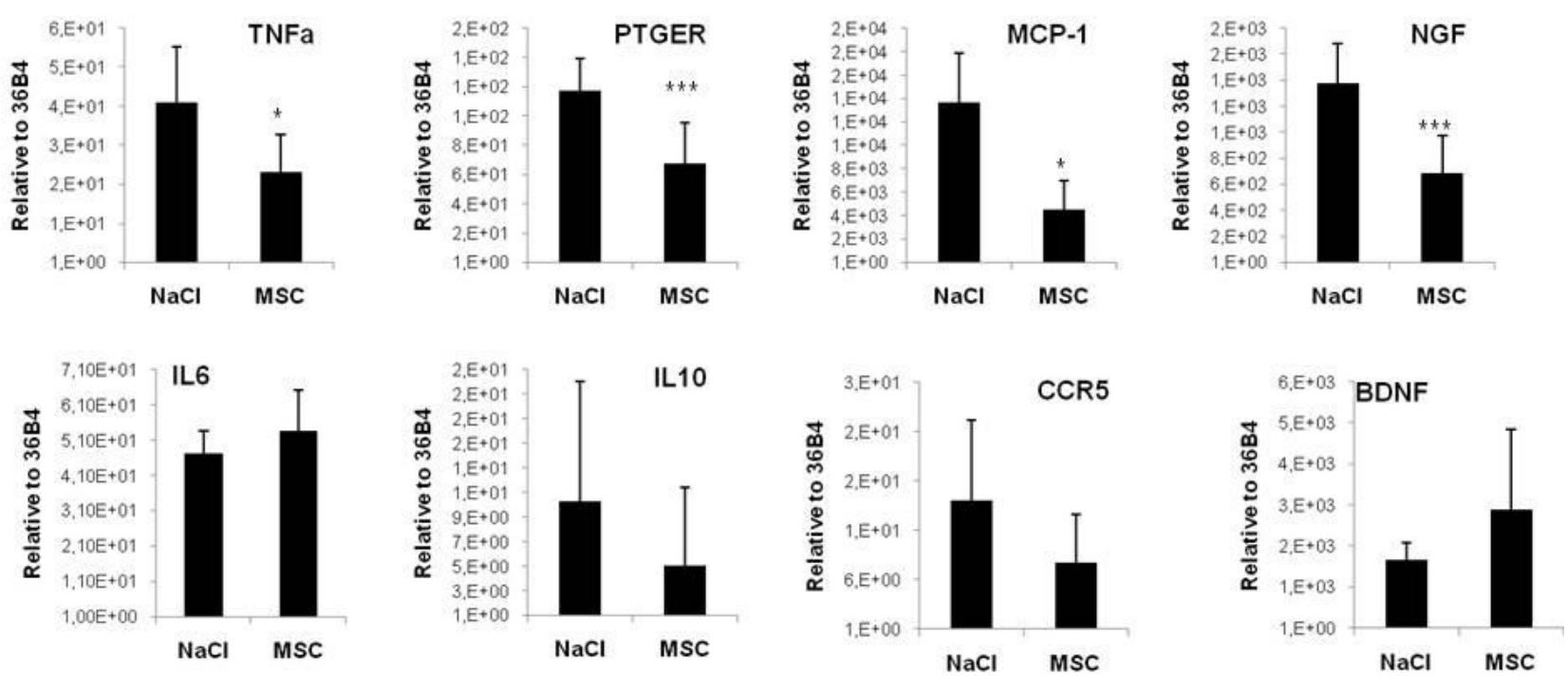

Figure 5

This article is protected by copyright. All rights reserved. 


\section{Gene expression in hippocampus on day 28}
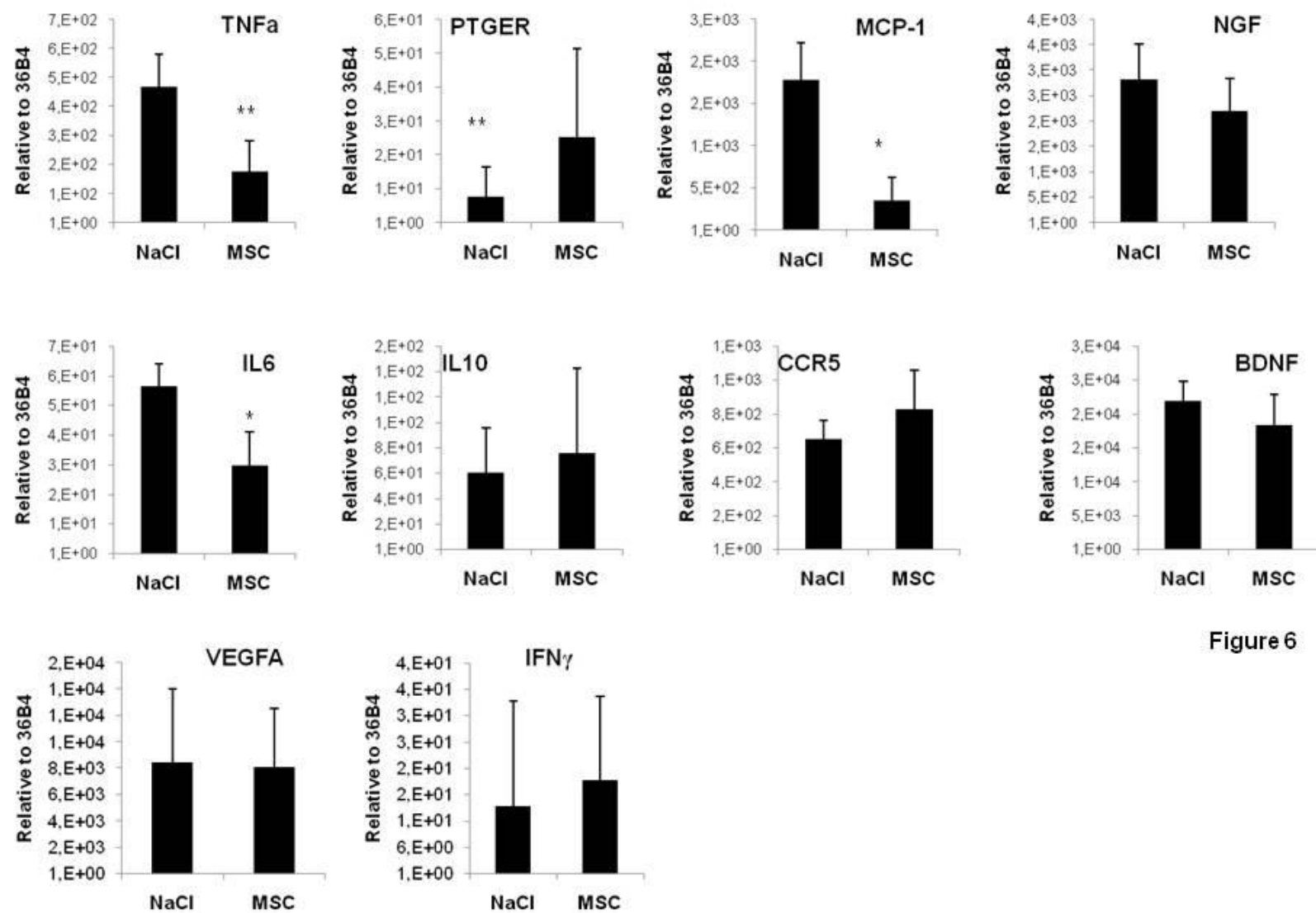

Figure 6

This article is protected by copyright. All rights reserved. 